The Perreaus and Mrs. Rudd $0 \times$ 
This page intentionally left blank 


$$
\begin{gathered}
\text { DONNA T. ANDREW } \\
\text { and RANDALL MCGOWEN }
\end{gathered}
$$

\section{The Perreaus}

\section{and Mrs. Rudd}

$0 \times 5$

\section{Forgery and Betrayal in Eighteenth-Century London}


University of California Press

Berkeley and Los Angeles, California

University of California Press, Ltd.

London, England

(C) 2001 by the Regents of the University of California

Library of Congress Cataloging-in-Publication Data

Andrew, Donna T., 1945-.

The Perreaus and Mrs. Rudd : forgery and betrayal in eighteenth-century London / Donna T. Andrew, Randall McGowen.

p. $\mathrm{cm}$.

Includes bibliographical references and index.

ISBN 0-520-22062-5 (cloth: alk. paper).

I. Perreau, Daniel, d. I776-Trials, litigation, etc.

2. Perreau, Robert, d. I776-Trials, litigation, etc.

3. Rudd, Margaret Caroline, b. I744 or 5-Trials, litigation, etc. 4. Trials (Forgery)-England-London. 5. Forgers-Great Britain. I. McGowen, Randall, I948-. II. Title.

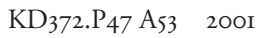

$345.42^{\prime} \mathrm{O} 263-\mathrm{dc} 2 \mathrm{I}$

$00-066655$

Manufactured in the United States of America

$\begin{array}{llllllllll}\text { IO } & 09 & 08 & 07 & 06 & 05 & 04 & 03 & 02 & \text { OI }\end{array}$

$\begin{array}{llllllllll}\text { IO } & 9 & 8 & 7 & 6 & 5 & 4 & 3 & 2 & \text { I }\end{array}$

The paper used in this publication meets the minimum requirements of ANSI/NISO Z39.48-I992 (R 1997)

(Permanence of Paper). 
For Rachel

$-\mathrm{RM}$

$0 \times 5$

For Emily, Eleanor, and Marion

- DTA 
This page intentionally left blank 
That, for which many their Religion,

Most men their Faith, all change their honesty,

Profit, (that guilded god) Commodity.

He that would grow damned Rich, yet live secure,

Must keep a case of Faces.

THOMAS DEKKER,

If This Be Not a Good Play, the Devil's in It ( I 6 I I ) 
This page intentionally left blank 